Article

\title{
Enhanced Thermostability and Enzymatic Activity of cel6A Variants from Thermobifida fusca by Empirical Domain Engineering
}

\author{
Imran Ali ${ }^{1, *}$, Hafiz Muzzammel Rehman ${ }^{2,3}$, Muhammad Usman Mirza ${ }^{4}$, \\ Muhammad Waheed Akhtar ${ }^{5}$, Rehana Asghar ${ }^{1}$, Muhammad Tariq ${ }^{1}, \operatorname{Rashid}^{\text {Ahmed }}{ }^{1}(\mathbb{D}$, \\ Fatima Tanveer ${ }^{6}$, Hina Khalid ${ }^{7}$, Huda Ahmed Alghamdi ${ }^{8}$ and Matheus Froeyen ${ }^{4}$ \\ 1 Department of Biotechnology, Mirpur University of Science and Technology (MUST), \\ Mirpur (AJK) 10250, Pakistan; rehanauaar@yahoo.com (R.A.); tariq.awan@must.edu.pk (M.T.); \\ hashmi133@yahoo.com (R.A.) \\ 2 Institute of Biochemistry and Biotechnology, University of the Punjab, Lahore 54590, Pakistan; \\ muzzammel.phd.ibb@pu.edu.pk \\ 3 Department of Human Genetics and Molecular Biology, University of Health Sciences, \\ Lahore 54590, Pakistan \\ 4 Department of Pharmaceutical and Pharmacological Sciences, Rega Institute for Medical Research, \\ Medicinal Chemistry, University of Leuven, B-3000 Leuven, Belgium; \\ muhammadusman.mirza@kuleuven.be (M.U.M.); mathy.froeyen@kuleuven.be (M.F.) \\ 5 School of Biological Sciences, University of the Punjab, Lahore 54590, Pakistan; mwa.sbs@pu.edu.pk \\ 6 Department of Biotechnology, Forman Christian College University, Lahore 54590, Pakistan; \\ 19-10544@formanite.fccollege.edu.pk \\ 7 Shaheed Zulfiqar Ali Bhutto Medical University, Islamabad 44000, Pakistan; \\ hina.khalid.mehmood@gmail.com \\ 8 Department of Biology, College of Sciences, King Khalid University, Abha 61413, Saudi Arabia; \\ hudaghamdi@kku.edu.sa \\ * Correspondence: aliimran@must.edu.pk; Tel.: +92-5827-961-999
}

Received: 26 June 2020; Accepted: 2 August 2020; Published: 7 August 2020

\begin{abstract}
Cellulases are a set of lignocellulolytic enzymes, capable of producing eco-friendly low-cost renewable bioethanol. However, low stability and hydrolytic activity limit their wide-scale applicability at the industrial scale. In this work, we report the domain engineering of endoglucanase (cel6A) of Thermobifida fusca to improve their catalytic activity and thermal stability. Later, enzymatic activity and thermostability of the most efficient variant named as cel6A.CBC was analyzed by molecular dynamics simulations. This variant demonstrated profound activity against soluble and insoluble cellulosic substrates like filter paper, alkali-treated bagasse, regenerated amorphous cellulose (RAC), and bacterial microcrystalline cellulose. The variant cel6A.CBC showed the highest catalysis of carboxymethyl cellulose $(\mathrm{CMC})$ and other related insoluble substrates at a $\mathrm{pH}$ of 6.0 and a temperature of $60^{\circ} \mathrm{C}$. Furthermore, a sound rationale was observed between experimental findings and molecular modeling of cel6A.CBC which revealed thermostability of cel6A.CBC at $26.85,60.85$, and $74.85^{\circ} \mathrm{C}$ as well as structural flexibility at $126.85^{\circ} \mathrm{C}$. Therefore, a thermostable derivative of cel6A engineered in the present work has enhanced biological performance and can be a useful construct for the mass production of bioethanol from plant biomass.
\end{abstract}

Keywords: endoglucanase (cel6A); domain engineering; Thermobifida fusca; molecular dynamics simulations; thermostable enzymes 


\section{Introduction}

Cellulose is the most abundant plant biomass found on earth and is extremely important for mankind due to its diverse applications. The evolving use of renewable non-food cellulosic plant biomass is a very attractive option for biofuel production. Biological depolymerization of cellulose biomass is accomplished by various types of cellulases, particularly endoglucanases, exoglucanases, and $\beta$-glucosidases. Endoglucanase cleaves cellulose polymer into oligopolymers of varying lengths, while exoglucanases attack reducing and/or non-reducing ends of cellulose yielding glucose or cellobioses, finally $\beta$-glucosidases convert cellobioses into fermentable sugar monomers. Despite the tremendous potential of cellulases in the conversion of plant biomass into useable bioethanol, their widespread application is restricted by their high cost and low efficacy, especially under harsh industrial conditions [1-5]. Enzymes with high thermostability are advantageous in saccharification processes owing to their better penetrating ability into lignocellulosic biomass for disorganization [6]. Furthermore, plant biomass degradations at elevated temperatures reduce the risk of microbial contamination and cooling costs after biomass pretreatment [7]. Therefore, tailor-made cellulases by molecular engineering with improved catalytic activity and thermostability is a prerequisite in order to be used in industrial applications.

Thermobifida fusca is a moderately thermophilic, major lignocellulolytic soil bacterium. It has been well known for its potential to produce various types of cellulases that can penetrate cellulose and lignocellulose residues to yield simple saccharide units [8]. Among various glycosyl hydrolase family 6 endoglucanases, endoglucanase (cel6A) of T. fusca is considered to be the most efficient reducing sugar producer, hence has the potential to be used in the biofuel industry [9]. Structurally, cel6A is a modular enzyme with a non-catalytic family 2 carbohydrate-binding module (CBM-II) at C-terminal. CBMs facilitate the adsorption of catalytic domain with the substrates [10], help in the alignment of enzyme-substrate in close proximity [11,12], and carry out hydrolysis by modification of substrate surfaces $[13,14]$.

There are very few reports on enzyme engineering for industrial applicability, particularly to improve the thermostability of cellulases $[1,15,16]$. Thermostable multimodular cellulases provide an excellent template for modification to enhance their suitability for industrial applications. The accessory roles of non-catalytic domains (CBMs) on thermal stability and insoluble substrate degrading efficiencies have been extensively reported by removing or grafting from respective catalytic domain/s [17-22]. MD simulations (molecular dynamics, is used to analyze physical movements of atoms and molecules by using computational tools) have been used in several studies to evaluate the factors regulating thermostability of enzymes [11,23-30] and to investigate the stability of the biomolecular complex and interaction attributes [31,32]. These include the thermal stable mechanisms of rubredoxin [33], nuclease [34], barnase [35], nitrile hydratase [36], adenylate kinase [37], carbonic anhydrase [38], carboxylesterase from Geobacillus stearothermophilus [39], psychrophilic esterase from Pseudoalteromonas haloplanktis [40], hyperthermophilic esterase from Archaeoglobus fulgidus [41], thermostable para-nitrobenzyl esterase from Bacillus subtilis [42], and CBMs from Clostridium cellulovorans [43,44].

In this study, we designed a group of cel6A variants, by deletion, insertion, and rearrangement of CBM-II as well as a catalytic domain (GH6). The engineered variants were expressed and characterized for different properties such as thermal stability and catalytic activity at different temperatures. Furthermore, catalytic functionality of cel6A variant was confirmed by application of multi-template homology modelling by using MODELLER v9.15. Thermostability of cel6A construct was investigated structurally to get an insight into the dynamic influence at different comparable temperatures. MD simulations were performed at four different temperatures $(26.85,60.85,74.85$, and $126.85{ }^{\circ} \mathrm{C}$ ) to develop a most effective rationale for the assessment of the impact of the factors governing enzyme's thermostability. The dynamic consequences of the enzyme construct were explored by calculating the root mean square deviation (RMSD) and root mean square fluctuation (RMSF) values for all $\mathrm{C} \alpha$ backbone atoms to identify the thermal sensitive regions as performed in some earlier 
studies [35-37,43]. The result obtained showed that cel6A is most active on soluble and insoluble cellulosic substrates. cel6A.CBC exhibited highest catalysis of carboxymethyl cellulose (CMC) at a $\mathrm{pH} 6.0$ and $60^{\circ} \mathrm{C}$. Furthermore, cel6A.CBC showed a good thermostability at $26.85,60.85$, and $74.85^{\circ} \mathrm{C}$ as well as structural flexibility at $126.85^{\circ} \mathrm{C}$ by molecular modelling assay. Therefore, a thermostable derivative of cel6A engineered in the present work showed a better performance and can be a useful variant for the production of bioethanol from cellulose.

\section{Materials and Methods}

\subsection{Reagents and Chemicals}

Plasmid and gene purification kits were purchased from GeneAll (Seoul, Korea). Restriction enzymes, T4 DNA ligase, and DNA/Protein markers were purchased from Thermo Scientific (Mississauga, Ontario, Canada). All other chemicals and reagents used in this study were purchased from Sigma Aldrich.

\subsection{PCR Amplification of cel6A Variants}

Construction scheme of cel6A derivatives is shown in Figure S1. All derivatives were amplified from cel6A gene as template [45] using the respective primers (Table S1). A PCR reaction mixture of $50 \mu \mathrm{L}$ was prepared as $1 \mathrm{X}$ Taq buffer, $0.4 \mathrm{mM}$ dNTPs, $1 \mu \mathrm{M}$ concentration of forward and reverse primers, 100 ng template DNA and 2 IU of Taq DNA polymerase. Gene amplification was done on Thermocycler Star 96, IRMECO with thermal conditions of $95^{\circ} \mathrm{C}$ for $3 \mathrm{~min}$ as initial denaturation, followed by 30 cycles of $95^{\circ} \mathrm{C}$ for $30 \mathrm{~s}$ denaturation, annealing at $58{ }^{\circ} \mathrm{C}$ for $30 \mathrm{~s}$, and extension at $72{ }^{\circ} \mathrm{C}$. Final extension of $20 \mathrm{~min}$ at $72{ }^{\circ} \mathrm{C}$ was also done. Amplified gene segments were gel purified and cloned into pTZ57R/T by InsT/A cloning kit. Preparation of E. coli DH5 $\alpha$ competent cells and transformation was done according to the standard protocols [46].

\subsection{Sub Cloning of cel6A Variants in Expression Vector}

Recombinant plasmids [pTZ-cel6A.C, -cel6A.BC, -cel6A.BCB, -cel6A.CBC, -cel6A.CBCB, and pET22b(+)] were extracted by GeneAll plasmid extraction kit, digested with respective restriction enzymes, and purified from $0.8 \%$ agarose gel by gel extraction kit (GeneAll). Sequential cloning (Figure S1) was done to ligate different gene segments into the expression vector pET22b $(+)$ to generate truncated, CBM-II transposition, addition, catalytic domain addition, and duplication of cel6A variants. The E. coli ( $\mathrm{DH} 5 \alpha)$ cells were chemically made competent according to the standard protocol [46]. These cells were transformed with cel6A variants, spread on ampicillin agar plates and incubated overnight at $37^{\circ} \mathrm{C}$. Transformants were confirmed by colony pick PCR and endonuclease digestion.

\subsection{Expression Analysis of cel6A Variants}

E. coli (BL21-CodonPlus (DE3)-RIPL) cells were chemically made competent and transformed with pcel6A.C, pcel6A.BC, pcel6A.BCB, pcel6A.CBC, pcel6A.CBCB. A single transformed colony was resuspended in $10 \mathrm{~mL} \mathrm{LB}$ broth containing ampicillin $\left(100 \mu \mathrm{g} \cdot \mathrm{mL}^{-1}\right)$ and incubated at $37^{\circ} \mathrm{C}$ for $16 \mathrm{~h}$. Fresh LB broth $(100 \mathrm{~mL})$ containing antibiotic was inoculated with $0.5 \mathrm{~mL}$ overnight grown transformed BL21 cells and placed at $37^{\circ} \mathrm{C}$ with $250 \mathrm{rpm}$ shaking in an orbital shaker. Cells were induced with $0.5 \mathrm{mM}$ IPTG when $\mathrm{OD}_{600}$ reached 0.4-0.6 and expression was analyzed on SDS-PAGE after $8 \mathrm{~h}$ of induction. For partial purification of cel6A engineered enzymes, induced cells were harvested at $6500 \mathrm{rpm}$ for $10 \mathrm{~min}$ and resuspended in $50 \mathrm{mM}$ phosphate buffer (pH 6) to final $\mathrm{OD}_{600}$ 1.0. Cells were lysed by ultra-sonication (Sonics vcx500, newtown, Connecticut, USA). Samples were processed at $30 \%$ amplitude for $30 \mathrm{~min}$ with $2.5 \mathrm{sec}$ pulse and $1 \mathrm{~min}$ interval. The lysate was heated at $60{ }^{\circ} \mathrm{C}$ for $30 \mathrm{~min}$ and centrifuged at $6500 \mathrm{rpm}$ for $15 \mathrm{~min}$. The supernatant was taken for enzymatic and physiological characterization. 


\subsection{Enzymatic Activity Assay}

Endoglucanase activity of cel6A variants was measured by incubating appropriately diluted enzyme solution $(0.5 \mathrm{~mL})$ with $1 \%$ carboxymethyl cellulose (CMC) as soluble substrate solution in $0.05 \mathrm{M}$ phosphate buffer having $\mathrm{pH} 6.0$ at $60^{\circ} \mathrm{C}$ for $10 \mathrm{~min}$. The reaction was halted by adding $0.5 \mathrm{~mL}$ $\mathrm{Na}_{2} \mathrm{CO}_{3}(1 \mathrm{M})$. Reducing sugars released by reaction was measured by adding $3 \mathrm{~mL}$ 3,5-Dinitrosalicylic acid (DNS) reagent (5.3 g of DNS, $9.9 \mathrm{~g} \mathrm{NaOH}, 15.3 \mathrm{~g}$ Na-K-tartarate and $4.15 \mathrm{~g}$ Na metabisulphite in $708 \mathrm{~mL}$ of water and adding $3.8 \mathrm{~mL}$ of phenol). The OD was measured at $600 \mathrm{~nm}$ against a blank [47]. Enzyme activity $(U)$ is the number of micromoles $(\mu \mathrm{m})$ of reducing sugars equivalent produced per minute under experimental conditions.

For hydrolytic activity assay on insoluble substrates, pre-treated bagasse, filter paper (FP), regenerated amorphous cellulose (RAC), and bacterial microcrystalline cellulose (BMCC) were used. BMCC was prepared by adding $5 \mathrm{~g}$ BMCC in distilled water containing $0.02 \%$ sodium azide and stirring overnight at $4{ }^{\circ} \mathrm{C}$. Bagasse was prepared by autoclaving $\left(15 \mathrm{lb} \cdot \mathrm{in}^{-2}\right)$ grounded bagasse powder with $0.5 \% \mathrm{NaOH}$ for $3 \mathrm{~h}$. Alkali treated bagasse was washed with distilled water to neutrality and dried. Activity assay was done by taking $10 \mathrm{mg}$ each of the substrates in an aliquot containing enzyme in $1 \mathrm{~mL}$ of $50 \mathrm{mM}$ phosphate buffer ( $\mathrm{pH}$ 6.0). Reducing sugars were measured after $12 \mathrm{~h}$ incubation in shaking water bath $\left(60^{\circ} \mathrm{C}\right)$ by DNS method. Blanks were prepared by the same procedure but without adding the enzyme. The concentration of the protein was determined using BSA (bovine serum albumin) as standard by the dye-binding method [48]. Assays were performed in triplicates. All enzymatic assays were performed as reported in previous studies $[49,50]$.

\section{6. $p H$ Stability Determination}

Optimum $\mathrm{pH}$ for cel6A variants was determined by suitably diluting enzymes with $50 \mathrm{mM}$ acetate, phosphate, Tris- $\mathrm{Cl}$, and borate-NaOH buffers, $\mathrm{pH} 3.0-5.0,5.5-7.5,8.0-9.0$, and 9.5-10.0, respectively. The $\mathrm{pH}$ stability was determined by incubating endoglucanase variants at $\mathrm{pH} 3.0-10.0$ for $120 \mathrm{~min}$ at room temperature $\left(25^{\circ} \mathrm{C}\right)$, and residual activity were assayed at regular intervals $(20 \mathrm{~min})$.

\subsection{Thermal Stability Determination}

Thermostability of cel6A variants was determined by incubating enzymes at different thermal conditions ranging from 50 to $75{ }^{\circ} \mathrm{C}$ for varying intervals up to $120 \mathrm{~min}$ and residual activity was assayed by incubating $500 \mu \mathrm{l}$ enzyme with $500 \mu \mathrm{L}$ of carboxymethyl cellulose $(1 \% w / v)$ as substrate dissolved in $50 \mathrm{mM}$ phosphate buffer ( $\mathrm{pH}$ 6.0) and resulting reducing sugars were determined by DNS method.

\subsection{Molecular Modeling Study}

Based on results of enzymatic assays, only the best thermostable construct was examined for better insight into the structural stability of domains on different comparable temperatures, namely, $26.85,60.85,74.85$, and $126.85^{\circ} \mathrm{C}$. For the structural study, engineered cel6 $\mathrm{A}$ variants were modelled through multi-template homology modelling by using MODELLER v9.15 [51,52]. The generated models were optimized and refined using a short 20-ns molecular dynamics (MD) simulation at standard temperature $\left(26.85^{\circ} \mathrm{C}\right)$ and pressure $(1 \mathrm{~atm})$. The stereochemical assessment of modelled structures and residue-by-residue geometry were validated by Molprobity [53]. All MD simulations were carried out using AMBER 18 simulation package [54]. The same MD simulation protocol was set up using the AMBER ff99SB force field [55], TIP3 water molecule model system [56], and neutralizing ions by creating an octahedral box extended $12.0 \AA$ around the solute. The same initial energy minimization, equilibration of the simulation system, and the following standard production run was utilized as described elsewhere $[31,57,58]$. To run MD simulation at different temperatures, the minimized systems of cel6A construct were equilibrated for 100 ps each at four temperatures $\left(26.85,60.85,74.85\right.$, and $\left.126.85^{\circ} \mathrm{C}\right)$ by position restrained molecular dynamics simulation to relax the 
solvent. The equilibrated systems were then subjected to a production run of $100 \mathrm{~ns}$ each at four different temperatures. The CPPTRAJ module of AMBER 18 was utilized for the trajectory analysis. The representative model was extracted after MD simulation and analyzed through Chimera v1.13 [59]. Molecular docking was performed using AutoDock Vina [60] to analyze the binding conformation of CMC substrate in respective catalytic domain. Binding pocket information was extracted by superimposing the co-crystalized catalytic domain of endo-1,4-glucanase cel6A from Thermobifida fusca in complex with methyl cellobiosyl-4-thio- $\beta$ - cellobioside (PDB ID: 2BOG) [61] and docking grid was exclusively build around the binding pocket. Details of protein preparation, optimization, and minimization are described in previous studies [57,62].

In order to access the quantitative description of binding affinity of cel6A constructs with bound CMC substrate, molecular mechanics-generalized born surface area (MM-GBSA) binding free energy calculations were performed using the AMBER 18 mmgbsa module. Binding free energy calculations by MMGBSA has been extensively discussed [63,64]. Total of 1000 snapshots from the whole MD trajectory of the complex was generated and binding free energy $\left(\Delta G_{\text {total }}\right)$, was calculated, $\Delta G_{\text {total }}$ is the sum of molecular mechanics energy $\left(\Delta \mathrm{E}_{\mathrm{MM}}\right)$, solvation free energy $\left(\Delta \mathrm{G}_{\mathrm{sol}}\right)$ contributions. $\Delta \mathrm{E}_{\mathrm{MM}}$ is further divided into internal energy $\left(\Delta \mathrm{E}_{\text {int }}\right)$, electrostatic $\left(\Delta \mathrm{E}_{\text {ele }}\right)$, van der Waals $\left(\Delta \mathrm{E}_{\mathrm{vdw}}\right)$ energy in the gas phase, whereas and $\Delta \mathrm{G}_{\mathrm{sol}}$ is divided into polar $\left(\Delta \mathrm{G}_{\mathrm{p}}\right)$ and non-polar $\left(\Delta \mathrm{G}_{\mathrm{np}}\right)$ contributions to the solvation free energy, as follows:

$$
\begin{gathered}
\Delta \mathrm{E}_{\mathrm{MM}}=\Delta \mathrm{E}_{\text {int }}+\Delta \mathrm{E}_{\text {ele }}+\Delta \mathrm{E}_{\mathrm{vdw}} \\
\Delta \mathrm{G}_{\text {sol }}=\Delta \mathrm{G}_{\text {polar }}+\Delta \mathrm{G}_{\text {nonpolar }} \\
\Delta \mathrm{G}_{\text {total }}=\Delta \mathrm{E}_{\mathrm{MM}}+\Delta \mathrm{G}_{\mathrm{sol}}
\end{gathered}
$$

\section{Results and Discussion}

Non-catalytic family 2 carbohydrate-binding module (CBM-II) and catalytic domain glycosyl hydrolase- 6 of endoglucanase cel6A were either deleted, inserted, or rearranged to engineer a suitable variant of cel6A that can withstand harsh conditions of $\mathrm{pH}$ and temperature for industrial applications. Then engineered cel6A variants were expressed and assessed for their enzymatic activity. The cel6A construct with higher thermostability was investigated structurally through long-run molecular dynamics simulations to get an insight of the thermostable behavior of enzyme at different comparable temperatures.

\subsection{Construction of Plasmids for Domain Engineered cel6A Variants}

Endoglucanase variants were constructed from catalytic and non-catalytic domains by addition, truncation, and transposition (Figure S2). All gene fragments after PCR amplification were gel purified, TA-cloned in pTZ57R/T vector and E. coli DH5 $\alpha$ cells were then transformed with recombinant vectors. The first construct encoding catalytic domain (cel6A.C) without CBM-II was sub-cloned after restriction from a pTZ-cel6A.C plasmid into T7 promoter-based pET22b(+) expression vector (Figure S1). Successful integration of the catalytic domain was confirmed by digesting pcel6A.C plasmid with NdeI and HindIII endonucleases, which released a fragment of $0.86 \mathrm{~kb}$ of cel6A.C.

To evaluate the positional/spatial effect of CBM-II, transposition of CBM-II from C-terminal of cel6A.CB to N-terminal was done by sequential cloning of CBM-II (272 bp), linker (110 bp), and then cel6A.Cn into pET22b(+) expression vector to generate pcel6A.BC (Figure S1). Restriction digestion of pcel6A.BC with NdeI and HindIII generated a $1.3 \mathrm{~kb}$ fragment corroborating the transposition of CBM-II from C-terminal to the N-terminal.

Later, three other variants; cel6A.BCB, cel6A.CBC, and cel6A.CBCB were constructed. A gene fragment was nicked from $p$ TZ-cel6A.CBn with BamHI and HindIII with an accurate size of $1.3 \mathrm{~kb}$ ligated to the $\mathrm{pCBM}-\mathrm{II}-\mathrm{L}$ vector digested with same endonucleases to generate pcel6A.BCB. The successful insertion was confirmed by the presence of $1.7 \mathrm{~kb}$ fragment after digesting with NdeI and HindIII 
enzymes. Similarly, additional catalytic domains and complete gene were inserted by removing stop codon and insertion of NcoI site at C-terminal of cel6A gene to generate pcel6A.CBCB. Inserts to be added were amplified with NcoI and HindIII sites at N-terminal of the catalytic domain and cel6A construct. Both cel6A.CBC and cel6A.CBCB was digested with NdeI and HindIII endonucleases to generate 2.2 and $2.7 \mathrm{~kb}$ restricted fragments, respectively, which substantiated the successful insertion (Figure S3). All constructs were sequenced in order to determine their inframe insertion and sequence fidelity. Other researchers had adopted similar domain rearrangement strategies for xylanase and endoglucanase genes of $C$. thermocellum $[49,50,65]$.

\subsection{Expression Analysis and Enzymatic Activities of cel6A Variants}

Recombinant expression of cel6A variants in E. coli BL21 CodonPlus (RIPL) was analysed in LB broth using IPTG as an inducer. All the variants were successfully expressed in E. coli BL21 CodonPlus (RIPL). Samples were taken after $8 \mathrm{~h}$ of $0.5 \mathrm{mM}$ IPTG induction, and the expression percentage of each variant was densitometrically calculated using Gene Tools software (G-box, Syngene). Protein expression levels of cel6A.C and cel6A.CBC was higher than all other constructs, while cel6A.BCBC showed minimum expression level (Table 1). The cells were lysed to evaluate the subcellular localization of cel6A variants. All variants were expressed in the soluble cytoplasmic fraction (Figure 1).

The enzymatic activity on soluble substrate CMC for cel6A.C, cel6A.BC, cel6A.BCB, cel6A.CBC, and cel6A.СВCB were 320, 290, 170, 600, and $250 \mathrm{U} \mathrm{l}^{-1} \mathrm{OD}^{-1} 0^{-1}$, respectively, while specific activities of these variants were 4.2, 4.3, 3.0, 7.2, and $6.9 \mathrm{U} \mathrm{mg}^{-1}$ enzymes, respectively (Table 1). Irwin et al., 1993 [66] carried out enzymatic activities of native cel6A and cel6A catalytic domain on different soluble and insoluble substrates, which supports our results of native cel6A.C and Cel6.BC. In a similar study, a fusion of CBM-II from Cel6B of T. fusca to the C-terminal of Cel5A of T. maritima and Cel9A of Alicyclobacillus acidocaldarius catalytic domains resulted in the improved hydrolytic activity of these engineered enzymes as compared to the native enzymes [28]. Our results showed enhanced endoglucanase activity by domain variant cel6A.CBC in comparison with native cel6A.C and cel6A.BC. Catalysis enhancement of the catalytic domains fused with CBMs on insoluble substrates has been reported previously due to many factors, including enzyme-substrate proximity [10]. Hydrolytic effect of cel6A variants on insoluble substrates was more pronounced. cel6A.C, cel6A.BC, cel6A.BCB, cel6ACBC, and cel6A.CBCB liberated $0.7,1.0,1.7,2.0$, and $1.5 \mu \mathrm{M}$ reducing sugars per $\mu \mathrm{M}^{-1}$ enzyme, respectively, from filter paper (FP). A similar pattern of hydrolysis was observed on other insoluble substrates as well. cel6A.BCB and cel6A.CBC was found more active on all insoluble substrates. cel6A.BCB produced 1.4, 2.6, and $0.28 \mu \mathrm{M}$, reducing sugars per $\mu \mathrm{M}^{-1}$ enzyme and cel6A.CBC produced 3.4, 5.4, and $0.9 \mu \mathrm{M}$, reducing sugars per $\mu \mathrm{M}^{-1}$ enzyme from bagasse, RAC, and BMCC, respectively (Table 1). Enzymatic activities of native cel6A were almost similar to that of cel6A.BC construct on soluble and insoluble substrates, which we reported previously $[49,50]$, Similar results were reported in a study in which an extra catalytic domain was added to the CelA of C. thermocellum [65]. In another study, the addition of CBMs to different endoglucanases increased their hydrolytic activities on Avicel [16]. 
Table 1. Expression levels of cel6A endoglucanase variants in E. coli and their relative activities against soluble and insoluble substrates.

\begin{tabular}{|c|c|c|c|c|c|c|c|c|c|}
\hline \multirow[b]{2}{*}{$\begin{array}{l}\text { Endoglucanase } \\
\text { (cel6A) Variants }\end{array}$} & \multirow[b]{2}{*}{$\begin{array}{l}\text { Cell Soluble } \\
\text { Protein } \\
\left(\mathrm{mg} \mathrm{l}^{-1} \mathrm{OD}_{600^{-1}}\right)\end{array}$} & \multirow{2}{*}{$\begin{array}{c}\text { Expression } \\
\text { Level of Variant } \\
\text { in Soluble Cell } \\
\text { Protein (\%) }\end{array}$} & \multirow[b]{2}{*}{$\begin{array}{c}\text { cel6A Yield } \\
\left(\mathrm{mg} \mathrm{l}^{-1} \mathrm{OD}_{600^{-1}}\right)\end{array}$} & \multicolumn{2}{|c|}{$\begin{array}{l}\text { Activity on } 1 \% \text { Carboxymethyl } \\
\text { Cellulose (CMC) }\end{array}$} & \multicolumn{4}{|c|}{$\begin{array}{c}\text { Activity on Insoluble Substrates a } \\
\text { ( } \mu \text { mol Reducing Sugar } \mu \mathbf{M}^{-1} \text { Enzyme) }\end{array}$} \\
\hline & & & & $\begin{array}{c}\text { Endoglu-Canase } \\
\text { Activity } \\
\text { (U 1 }^{-1} \mathrm{OD}_{600^{-1}}\end{array}$ & $\begin{array}{l}\text { Specific Activity } \\
\text { (U mg } \text { m }^{-1} \text { Enzyme) }\end{array}$ & $\begin{array}{l}\text { Filter Paper } \\
\quad \text { (FP) }\end{array}$ & Bagasse & $\begin{array}{c}\text { Regenerated } \\
\text { Amorphous } \\
\text { Cellulose } \\
\text { (RAC) }\end{array}$ & $\begin{array}{c}\text { Bacterial } \\
\text { Microcrystalline } \\
\text { Cellulose } \\
\text { (BMCC) }\end{array}$ \\
\hline cel6A.C & $170 \pm 8.7$ & $45 \pm 2.9$ & $76.5 \pm 3.9$ & $320 \pm 12.5$ & $4.19 \pm 0.05$ & $0.7 \pm 0.02$ & $0.9 \pm 0.06$ & $1.3 \pm 0.06$ & $0.24 \pm 0.03$ \\
\hline cel6A.BC & $168 \pm 9.2$ & $40 \pm 3.5$ & $67.2 \pm 1.4$ & $290 \pm 10.2$ & $4.32 \pm 0.05$ & $1.0 \pm 0.05$ & $1.4 \pm 0.03$ & $2.6 \pm 0.12$ & $0.28 \pm 0.01$ \\
\hline cel6A.BCB & $190 \pm 8.4$ & $30 \pm 2.1$ & $57.0 \pm 0.6$ & $170 \pm 9.9$ & $2.98 \pm 0.03$ & $1.7 \pm 0.09$ & $2.2 \pm 0.14$ & $3.2 \pm 0.18$ & $0.60 \pm 0.03$ \\
\hline cel6A.CBC & $185 \pm 8.0$ & $45 \pm 3.0$ & $83.3 \pm 1.3$ & $600 \pm 14.8$ & $7.20 \pm 0.13$ & $2.0 \pm 0.11$ & $3.4 \pm 0.11$ & $5.4 \pm 0.25$ & $0.90 \pm 0.02$ \\
\hline cel6A.СВCB & $180 \pm 10.3$ & $20 \pm 1.4$ & $36.0 \pm 0.3$ & $250 \pm 10.7$ & $6.94 \pm 0.31$ & $1.5 \pm 0.13$ & $2.0 \pm 0.10$ & $1.7 \pm 0.14$ & $0.56 \pm 0.09$ \\
\hline
\end{tabular}

a Endoglucanse activities were performed at $60^{\circ} \mathrm{C}(\mathrm{pH} 6.0)$ in triplicates. 


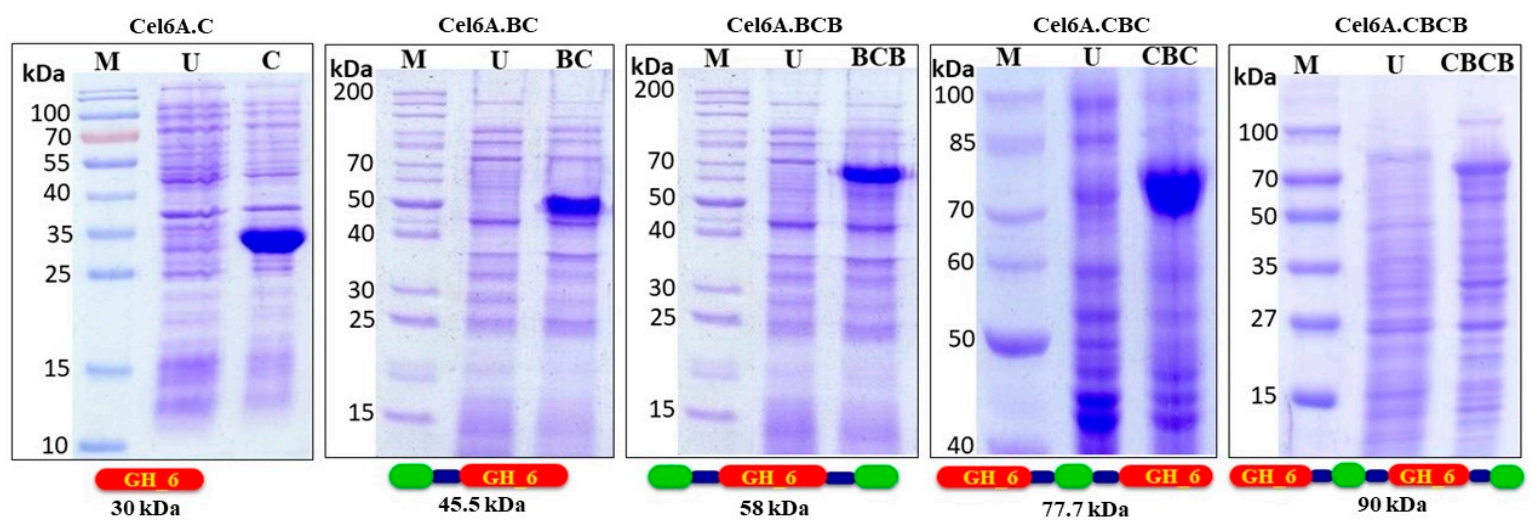

Figure 1. SDS-PAGE (12\%) analysis of total E. coli BL-21 CodonPlus (RIPL) proteins expressing cel6A.C, cel6A.BC, cel6A.BCB, cel6A.CBC and cel6A.CBCB after induction with 0.4 mM IPTG. M: Protein Marker, U: Uninduced sample.

\subsection{Physiological Characterization of cel6A Variants}

\subsubsection{Effect of Temperature on cel6A Variants}

The endoglucanase activity of engineered cel6A constructs showed almost similar hydrolytic activity pattern by retaining more than $80 \%$ endoglucanase activity at $60-70{ }^{\circ} \mathrm{C}$. The optimum temperature for endoglucanase activity was $60^{\circ} \mathrm{C}$ for all the cel6A variants where they showed $100 \%$ enzymatic activity. There was a significant difference between the enzymatic activities of native cel6A and engineered domain variants. The variant cel6A.CBC showed the most thermophilic property. The cel6A.CBC depicted enhanced endoglucanase activity in comparison with native cel6A at 70 ( $87 \%$ vs. $84 \%$ ), at 75 (73\% vs. $67 \%$ ), and at $80(45 \%$ vs. $33 \%$ ). (Figure 2$)$.

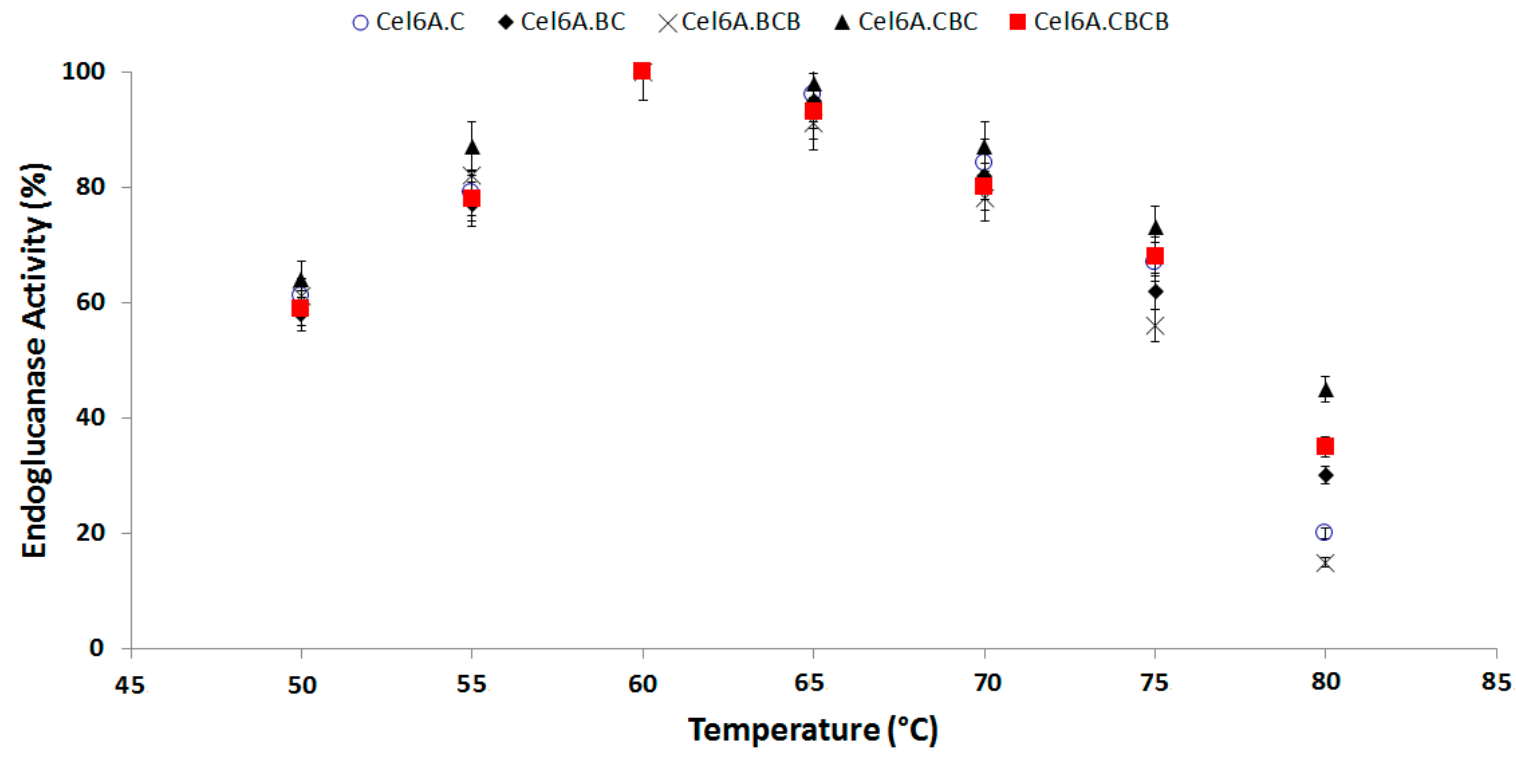

Figure 2. Effect of Temperature on hydrolytic activity of cel6A variants against CMC.

Thermostability assays of the recombinant constructs were performed at six pre-incubation temperatures $\left(50,55,60,65,70\right.$, and $\left.75^{\circ} \mathrm{C}\right)$, for $2 \mathrm{~h}$. At 50, 55, and $60^{\circ} \mathrm{C}$ pre-incubation temperatures, all recombinant enzymes as well as native enzyme maintained more than $85 \%$ of residual activity after $2 \mathrm{~h}$ of incubation showing no appreciable difference in their activity. On the other hand, in a reaction assay at a pre-incubation temperature of $65^{\circ} \mathrm{C}$, a slight difference was observed in the residual activity of different recombinant constructs. The observed residual activities after $2 \mathrm{~h}$ incubation were 64,71 , 
$64,58,78$, and 61 of recombinant enzymes cel6A.CB (cel6A.CB is native cel6A), cel6A.C, cel6A.BC, cel6A.BCB, cel6A.CBC, and cel6A.CBCB, respectively. There was a substantial difference between the residual activities of cel6A.CBC and other enzymes at pre-incubation temperatures of 70 and $75{ }^{\circ} \mathrm{C}$. The cel6A.CBC maintained a residual activity of $62 \%$ at $70{ }^{\circ} \mathrm{C}$ after $60 \mathrm{~min}$ while all other enzymes decreased to less than $30 \%$. On pre-incubation at $75{ }^{\circ} \mathrm{C}$, cel6A.CBC and cel6A.C showed residual activity of $24 \%$ and $20 \%$, respectively, after $60 \mathrm{~min}$ and $10 \%$ and $0 \%$ after $90 \mathrm{~min}$, whereas all other enzymes lost catalytic activity at $75^{\circ} \mathrm{C}$ in less than $60 \mathrm{~min}$ (Figure 3 ).
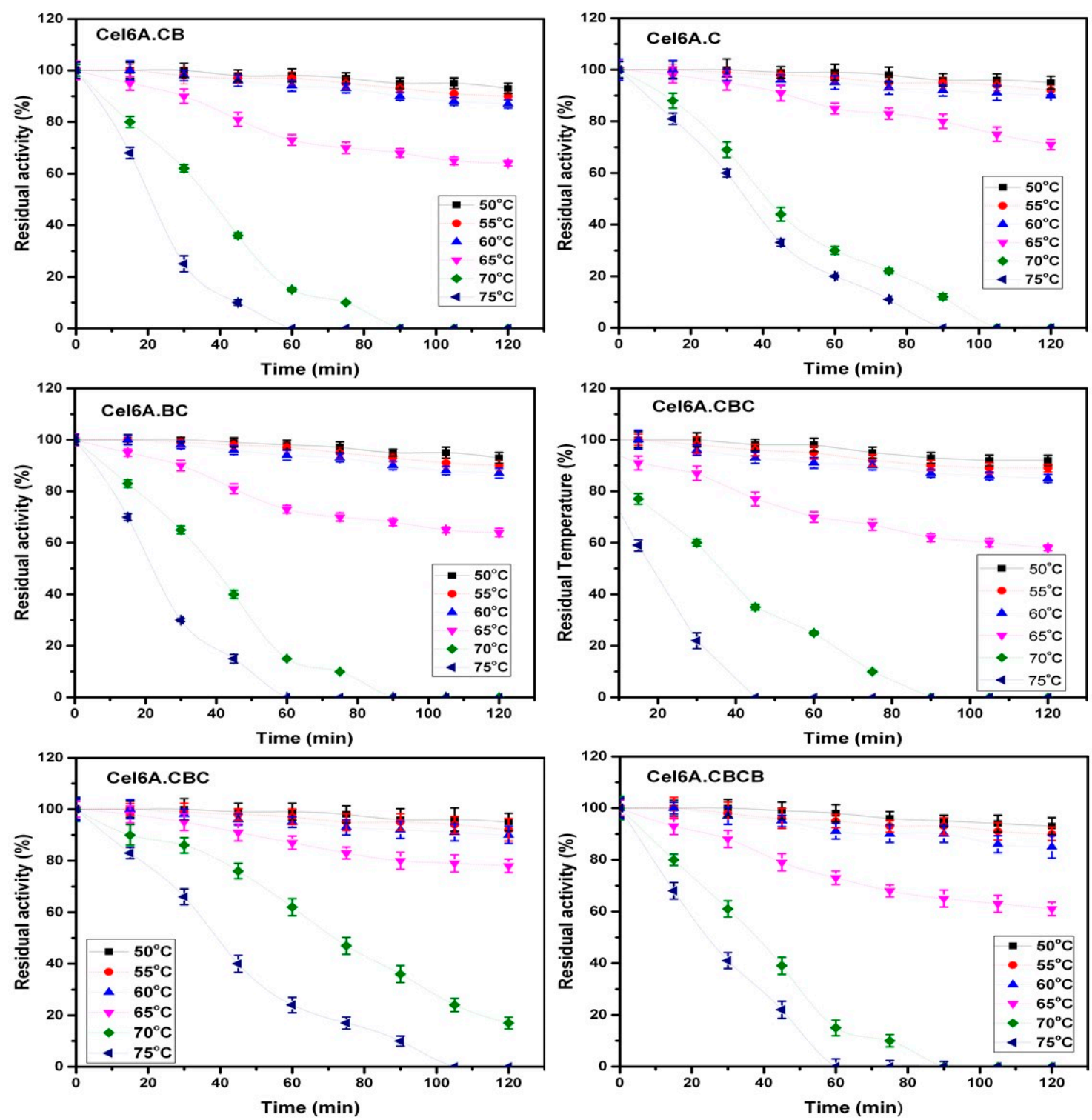

Figure 3. Residual activities of cel6A variants after incubation at varying temperatures.

\subsubsection{Effect of $\mathrm{pH}$ on cel6A Variants}

Optimum enzymatic activity of endoglucanase variants was measured on a broad $\mathrm{pH}$ range of 3.0 to 10.0. All variants retained more than $80 \%$ hydrolytic activity between $\mathrm{pH}$ 5.0-8.0. The hydrolytic assay was performed after incubating each of cel6A variants at any of this $\mathrm{pH}$ at room temperature for $2 \mathrm{~h}$. Enzymatic activity gradually decreased below pH 5.0 and above $\mathrm{pH}$ 8.0, with optimum activity at $\mathrm{pH} 6.5$ for all cel6A variants (Figure 4). cel6A. cel6A.CBC retained more enzymatic activity in comparison with native cel6A at pH 9.0 (66\% vs. 61\%), at pH 9.5 (58\% vs. 55\%), and at pH 10.0 (53\% vs. $51 \%)$. 


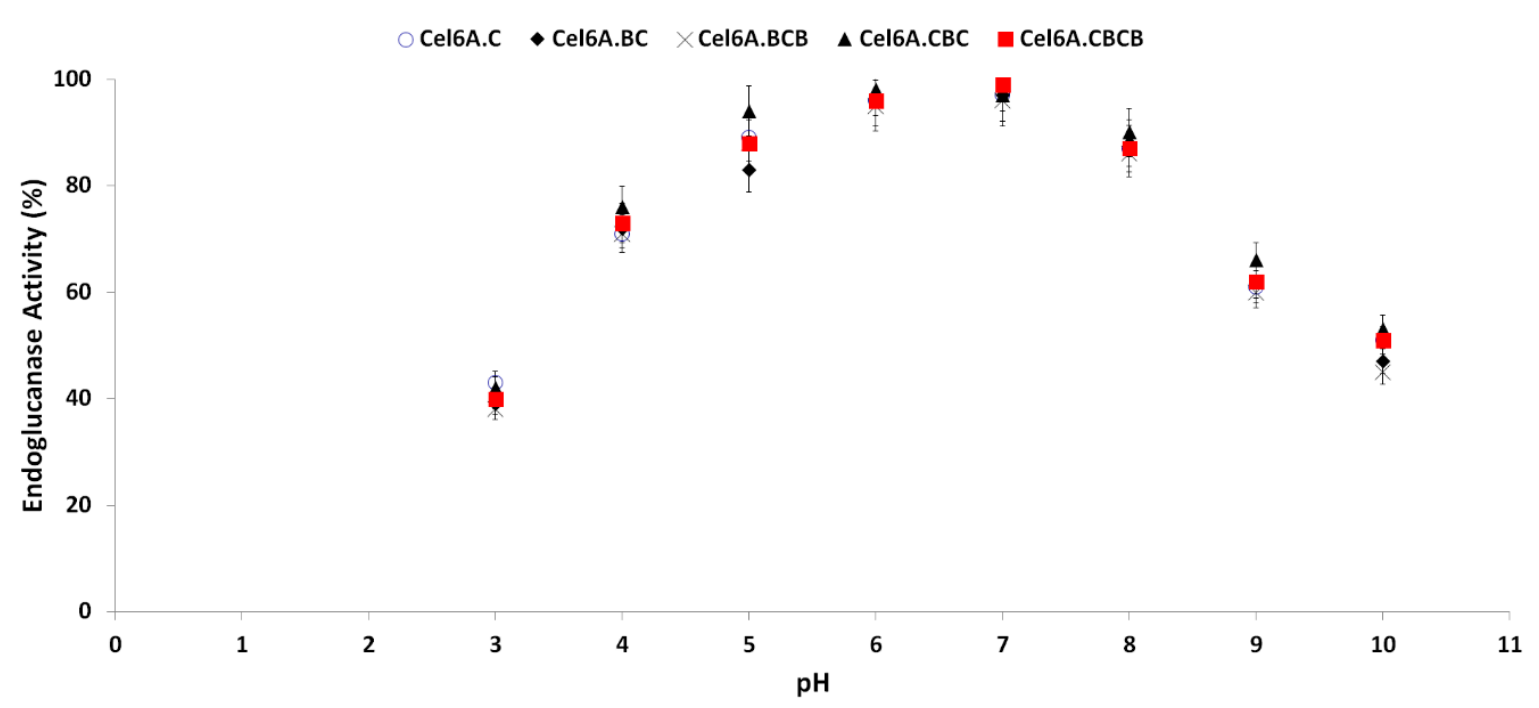

Figure 4. Effect of $\mathrm{pH}$ on hydrolytic activity against $\mathrm{CMC}$ of cel6A variants.

\subsection{Molecular Modeling Analysis}

Among all thermostable engineered cel6A constructs, cel6A.CBC showed enhanced enzymatic activity and was found to be more stable at a higher temperature (Figures 2 and 3 ). It was interesting to explore the temperature influence on the dynamics of cel6A.CBC. Homology model of cel6A. CBC construct was generated by a multi-template approach using MODELLER. To build cel6A.CBC model, an X-ray resolved endoglucanase structure from Thermobifida fusca was retrieved (PDB ID: 2BOG) [61] to generate $\mathrm{N}$ (residues 1-287) and C-catalytic domain (residues 407-692), whereas a carbohydrate-binding type-2 (CBM-II) domain (PDB ID: 3NDZ; Identity: 42\%; Probability: 98\%; E-value: $2.3 \times 10^{-5}$ ) was used to build the binding domain (residues 288-406). The wild-type cel6A.CB model was merely generated by truncating the C-catalytic domain from cel6A.CBC model. Both models were optimized and refined using a short $20 \mathrm{~ns} \mathrm{MD}$ simulation. Then, these models were validated using MolProbity to check all-atom contacts and geometry (Table 2). The MolProbity score, which combines the clash score, rotamer, and Ramachandran estimations into a single score (normalized to be on the same scale as X-ray resolution), was 1.68 and 1.70 (99th percentile) for cel6A.CBC and cel6A.CB respectively. The MD optimized cel6A.CBC model showed 90.27\% (622/689) residues, while cel6A.CB exhibited 90.9\% (370/407) residues in Ramachandran favoured (>98\%) regions. Furthermore, cel6A.CBC model showed 97.9\% (674/689) residues placed in Ramachandran allowed region (>99.8\%) with 11 (1.59\%) outliers, whereas cel6A.CB model showed 96.8\% (394/407) residues with 7 outliers $(1.71 \%$ ) (Table 2). After model generation, molecular docking studies were also carried out to explore the protein-ligand associations. Due to the presence of the same catalytic unit in both models having the same binding site residues, the docking affinities of CMC were similar (docking score: $-6.9 \mathrm{Kcal} / \mathrm{mol}$ ) in both constructs. 
Table 2. Summary statistics of all-atom contacts and stereochemistry of cel6A.CB and cel6A.CBC after refinement through molecular dynamics (MD) simulations.

\begin{tabular}{|c|c|c|c|c|c|}
\hline \multirow{2}{*}{$\begin{array}{l}\text { All-Atom } \\
\text { Contacts }\end{array}$} & \multirow[t]{2}{*}{ Summary Statistics } & \multicolumn{2}{|c|}{$\begin{array}{l}\text { cel6A.CB } \\
(20 \mathrm{~ns})\end{array}$} & \multicolumn{2}{|c|}{$\begin{array}{c}\text { cel6A.CBC } \\
(20 \mathrm{~ns})\end{array}$} \\
\hline & & \multicolumn{2}{|c|}{0.94} & \multicolumn{2}{|c|}{1.13} \\
\hline \multirow{9}{*}{$\begin{array}{l}\text { Protein } \\
\text { Geometry }\end{array}$} & Poor rotamers & $8 / 407$ & $1.96 \%$ & $16 / 689$ & $2.32 \%$ \\
\hline & Favored rotamers & $372 / 407$ & $91.4 \%$ & $632 / 689$ & $91.72 \%$ \\
\hline & Ramachandran outliers & $7 / 407$ & $1.71 \%$ & $11 / 689$ & $1.59 \%$ \\
\hline & Ramachandran favored & $370 / 407$ & $90.9 \%$ & $622 / 689$ & $90.27 \%$ \\
\hline & Ramachandran allowed & $394 / 407$ & $96.8 \%$ & $674 / 689$ & $97.9 \%$ \\
\hline & MolProbity score & \multicolumn{2}{|c|}{1.70} & \multicolumn{2}{|c|}{1.68} \\
\hline & $C \beta$ deviations $>0.25 \AA$ & 23 & $5.65 \%$ & 51 & $7.4 \%$ \\
\hline & Bad bonds: & $30 / 2194$ & $1.37 \%$ & $62 / 5038$ & $1.23 \%$ \\
\hline & Bad angles: & $74 / 3014$ & $2.45 \%$ & $105 / 6939$ & $1.51 \%$ \\
\hline Peptide & Cis Prolines: & $0 / 20$ & $0.00 \%$ & $0 / 52$ & $0.00 \%$ \\
\hline Omegas & Cis nonProlines: & 1 & $0.24 \%$ & 3 & $0.42 \%$ \\
\hline
\end{tabular}

\subsection{Global Structural Stability}

Since protein denaturation usually arises in microsecond time scale $[67,68]$, it is difficult to investigate the protein unfolding at normal temperatures using molecular dynamic simulations. To analyze denaturation process in cel6A constructs within the reasonable time limits, much higher temperatures are used. MD simulations procedures have been performed at higher temperatures previously to study the thermostability in various enzymes $[15,36,38,69,70]$. To investigate the global structural stability of cel6A.CBC, a comparative molecular dynamics (MD) simulation, was carried out at different temperatures. Based on the endoglucanase activity results, four temperatures were selected, including room temperature $\left(26.85^{\circ} \mathrm{C}\right)$, the optimal temperature for endoglucanase activity by all constructs $\left(60.85^{\circ} \mathrm{C}\right)$, the highest temperature where cel6A.CBC still showed slight thermostability with more than $80 \% \mathrm{CMCase}$ activity $\left(74.85^{\circ} \mathrm{C}\right)$, and one extreme temperature $\left(126.85^{\circ} \mathrm{C}\right.$; to explore the thermal sensitive regions). MD simulations for a total of $100 \mathrm{~ns}$ were carried out at each temperature range to observe deviations and fluctuations implicated in conformational changes of cel6A.CBC.

Structural thermal fluctuations of proteins are intrinsically related to their functions [71]. Therefore, we initially investigated the temperature influence on global structure stability in terms of root mean square deviations (RMSD) of the cel6A.CBC C $\alpha$-backbone atoms during the simulation. All MD simulations analysis is illustrated in Figure 5. Figure 5A evaluates the backbone RMSD trajectories from the corresponding initial structure as a function of time at four different temperatures. As expected, cel6A.CBC remained stable during the entire simulation period of $100 \mathrm{~ns}$ at $26.85^{\circ} \mathrm{C}$ and $60.85^{\circ} \mathrm{C}$, and converged between 1 to $1.5 \AA$ and showed close resemblance with the initial structures (Figures $5 \mathrm{~A}$ and 6). Throughout the simulation, both catalytic domains pulled inward over the CBM-II domain and adopted a closed conformation over time (Figure $6 \mathrm{~A}-\mathrm{C}$ ). At $74.85^{\circ} \mathrm{C}$, where cel6A.CBC showed CMCase activity, and all other constructs lost their activities, the cel6A.CBC $\mathrm{C} \alpha$-backbone atoms remained stable for first $20 \mathrm{~ns}$ and reached equilibrium at about $4 \AA$ and attained a value of $5 \AA$ which showed stable RMSD for the rest of the simulation. Although it fluctuated slightly in that period but remained converged within $1.5 \AA$ radius, demonstrated more favourable conformation. At $126.85^{\circ} \mathrm{C}$ $(400 \mathrm{~K})$ simulations, cel6A.CBC C $\alpha$-backbone atoms increased in the beginning, slightly stable at $4 \AA$, and attained a high value of $7.5 \AA$ (Figure $5 \mathrm{~A}$ ). Thus, increasing temperature up to $126.85^{\circ} \mathrm{C}(400 \mathrm{~K})$ showed little stability and significant structural distortions were examined only at a higher temperature of $126.85^{\circ} \mathrm{C}$. 
A

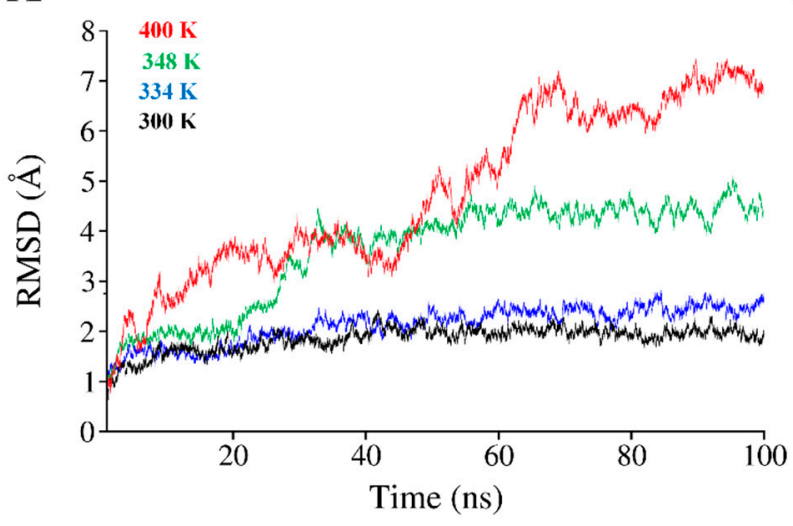

B

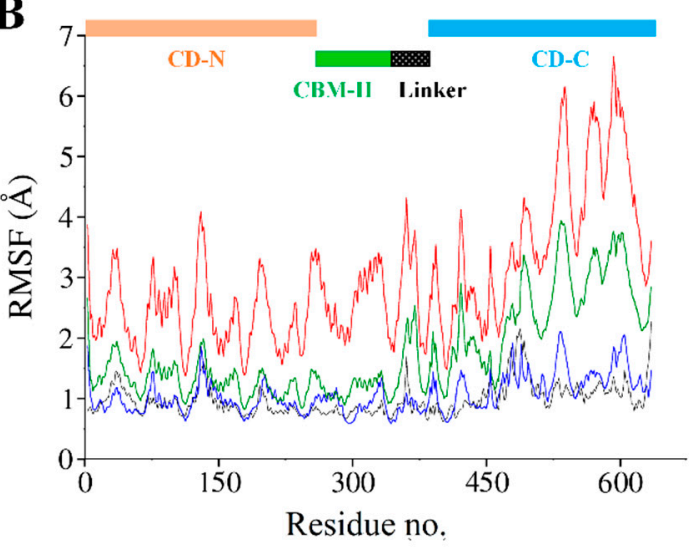

Figure 5. (A) Time dependent all backbone atom root mean square deviation (RMSD) of cel6A.CBC, (B) Root mean square fluctuation (RMSF) as a function of residue number of cel6A.CBC at different temperatures. Each trajectory is colored as follows: $26.85^{\circ} \mathrm{C}$ (black), $60.85^{\circ} \mathrm{C}$ (blue), $74.85^{\circ} \mathrm{C}$ (green), and $126.85^{\circ} \mathrm{C}$ (red).

A

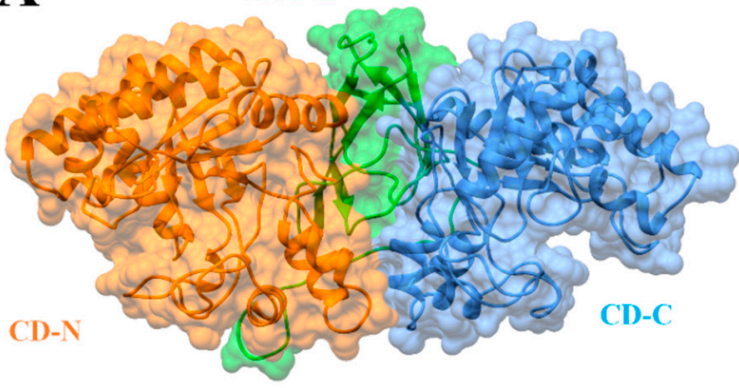

Starting Structure (Cel6A.CBC)

C

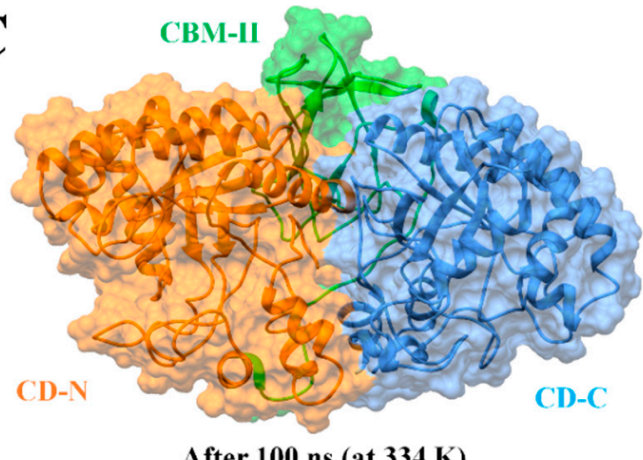

B CBM-II

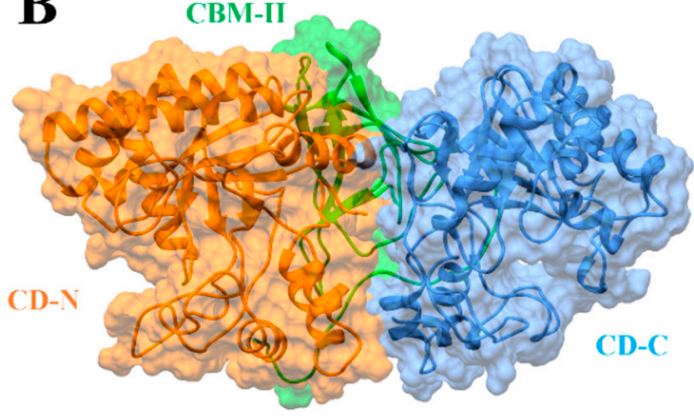

After 50 ns (at 334 K)

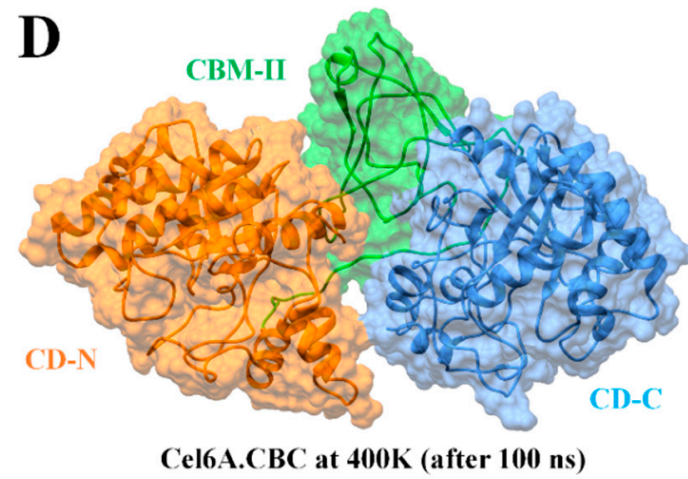

Figure 6. Molecular surface representation of cel6A.CBC construct with catalytic domains are colored as orange at N-terminal (CD-N) and cauliflower at C-terminal (CD-C), while CBM-II connecting the catalytic domains is colored green. (A) The initial conformation of cel6A.CBC before MD simulation. (B) The conformation of cel6A.CBC at an optimum temperature of $60.85{ }^{\circ} \mathrm{C}$ after $50 \mathrm{~ns}$. (C) The conformation of cel6A.CBC at an optimum temperature of $60.85^{\circ} \mathrm{C}$ after $100 \mathrm{~ns}$. (D) The conformation of cel6A.CBC at an extreme temperature of $126.85^{\circ} \mathrm{C}$ after $100 \mathrm{~ns}$.

\subsection{Structural Flexibility}

To confirm the stability of cel6A.CBC at different temperatures, the average root-mean-square-fluctuations (RMSF) were also calculated, which could give us the qualitative comparison of the fluctuations of different regions of cel6A.CBC construct. Figure 5B compares the RMSFs of each residue for every temperature simulations for cel6A.CBC. At 26.85 and $60.85{ }^{\circ} \mathrm{C}$, 
most regions of cel6A.CBC showed slight fluctuations at increasing temperature, indicated cel6A.CBC is rather thermostable at these temperatures. At $74.85^{\circ} \mathrm{C}$, although the $\mathrm{N}$-terminal catalytic domain showed less fluctuations, CBM-II domain connecting to the $\mathrm{C}$-terminal catalytic domain experienced significant fluctuations, which directed larger fluctuations up to $\sim 4 \AA$ in C-terminal catalytic domain. These results agreed with the experimental thermostability assays, where cel6A.CBC still showed slight thermostability at $74.85^{\circ} \mathrm{C}$ with more than $80 \%$ CMCase activity. When the temperature was elevated to $126.85^{\circ} \mathrm{C}$, most of the residues became highly mobile due to the denaturing of secondary structural at extreme temperature. Whereas, the linker displayed systematically less fluctuations throughout simulation at other temperatures (Figure 5B). Figure 6D clearly illustrated the loss of $\beta$-sheet content in CBM-II domain, which initiated the unfolding process and both catalytic domains moved apart at a higher temperature (at $126.85^{\circ} \mathrm{C}$ ). Contrary to that, both catalytic domains remained closer in a compact confirmation at other temperatures $\left(26.85,60.85\right.$, and $\left.74.85^{\circ} \mathrm{C}\right)$ throughout 100 -ns simulations (Figures 5 and 6).

\subsection{Binding Free Energy Calculations}

In order to provide quantitative descriptions, i.e., the absolute binding free energies of cel6A.CBC to the CMC substrate binding, MM-GBSA module of Amber 18 was utilized to analyze the intermolecular contributions with bound CMC. In order to compare the binding free energy, cel6A.CBC was compared to its wild-type cel6A.CB., as cel6A.CBC contained two catalytic domains. Therefore a docked complex was obtained bound with two CMC molecules in both catalytic domains, as shown in Figure 7.

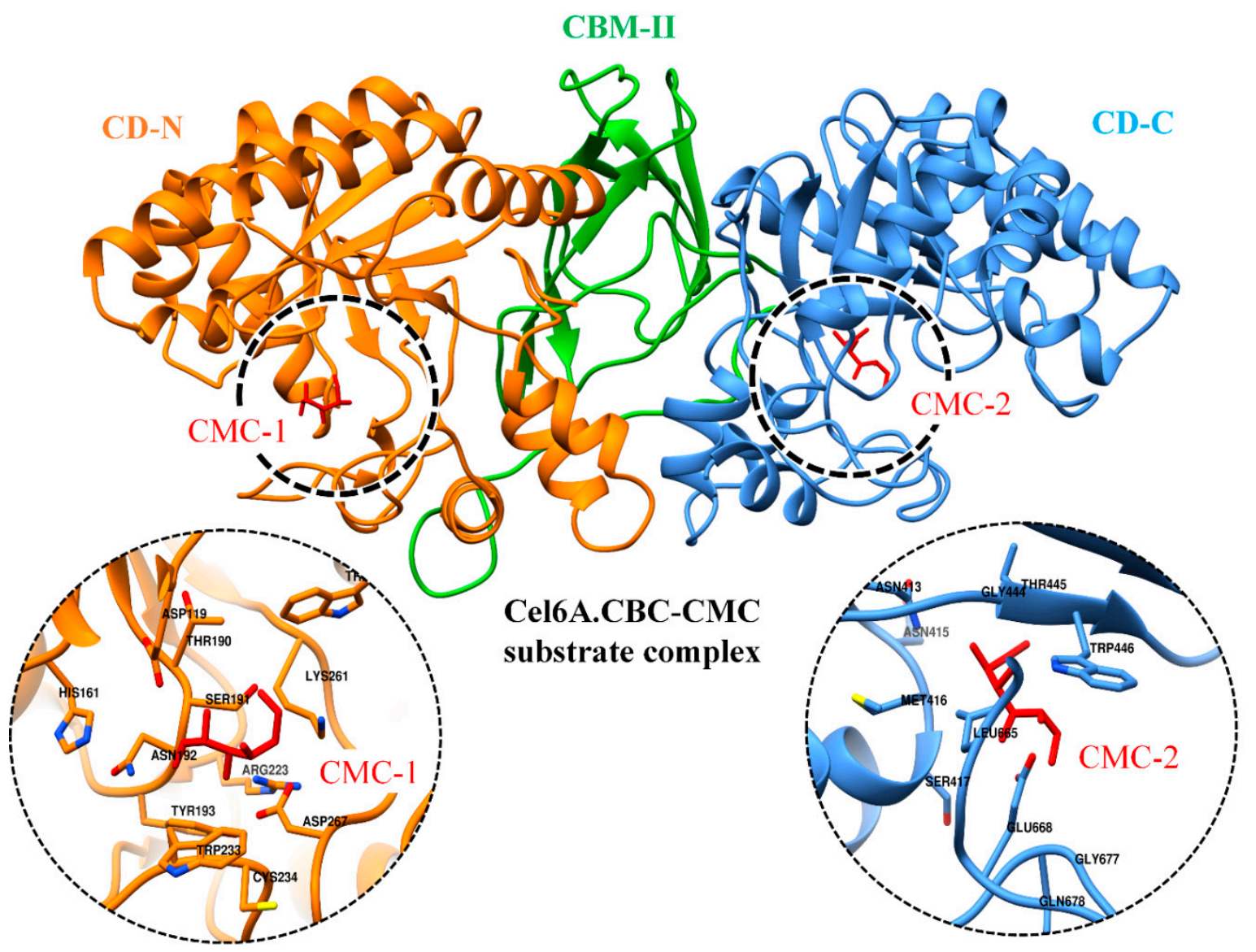

Figure 7. Docked conformation of CMC substrates (red sticks) as CMC1 and CMC2 with N and C-terminal catalytic domains of cel6A.CBC, respectively. The zoomed-in on left and right displaying the binding site residues in respective catalytic domains. 
For wild-type cel6A.CBC, a simulation system was configured with both $\mathrm{CMC}$ molecules, and $\mathrm{MD}$ simulation was performed for 20 ns. For wild-type cel6A.CB, a best-docked conformation bound with $\mathrm{CMC}$ molecule was processed for the same time duration. A total of 1000 snapshots were obtained from the whole $20 \mathrm{~ns}$ MD trajectory of each complex, and average binding free energy $\left(\Delta \mathrm{G}_{\text {total }}\right)$ was calculated (Table 3). Although there was no direct comparison for the MM-GBSA results obtained from this study, the reliability of MM-GBSA method in the calculation of substrate binding free energies has been descriptively studied for the recognition of cellulose by the CBM $[43,44]$. The calculated binding free energy of cel6A.CBC/CMC complex $\left(\Delta \mathrm{G}_{\text {total }}=-20.6 \mathrm{kcal} / \mathrm{mol}\right)$ was lower than cel6A.CB $/ \mathrm{CMC}$ $\left(\Delta \mathrm{G}_{\text {total }}=-12.0 \mathrm{kcal} / \mathrm{mol}\right)$, suggested favorable binding affinity in comparison. Such a difference in binding free energies was evident due to the presence of an additional catalytic domain in cel6A.CBC, which established additional intermolecular interactions with the second CMC molecule. These results were in fairly good agreement with the experiment, where higher endoglucanase activity (600 $\mathrm{U} \mathrm{I}^{-1}$ OD $\left.600^{-1}\right)$ and specific CMCase activity $\left(7.2 \mathrm{U} \mathrm{mg}^{-1}\right.$ enzyme) were observed for cel6A.CBC construct as compared to the other constructs (Table 1). MM-GBSA values of cel6A.CBC/CMC complex was also observed at different temperatures (using the same procedure as described above) to further insight into the binding energy differences. The MM-GBSA values remained consistent for the first three temperatures $\left[\Delta \mathrm{G}_{\text {total }}=-20.6 \mathrm{kcal} / \mathrm{mol}\right.$ at $26.85^{\circ} \mathrm{C}(300 \mathrm{~K}) ;-21.5 \mathrm{kcal} / \mathrm{mol}$ at $60.85^{\circ} \mathrm{C}(334 \mathrm{~K})$; $-19.2 \mathrm{kcal} / \mathrm{mol}$ at $74.85^{\circ} \mathrm{C}(348 \mathrm{~K})$ ] but gradually reduced to $-8.9 \mathrm{kcal} / \mathrm{mol}$ at $126.85{ }^{\circ} \mathrm{C}$ (Table 3). The energy difference at the extreme $126.85^{\circ} \mathrm{C}$ temperature was obvious from the dramatic distortion of C-terminal catalytic domain due to the loss of $\beta$-sheet content in the CBM-II domain (Figure 6D), which triggered higher fluctuations in the catalytic domain bound to CMC substrate, thus diminished catalytically important electrostatic and van der Waals interactions.

Table 3. Molecular mechanics generalized Born surface area (MMGBSA) binding free energy results for cel6A.CB at standard temperature $\left(26.85^{\circ} \mathrm{C}\right)$ and cel6A.CBC at different temperatures.

\begin{tabular}{cccccc}
\hline \multirow{2}{*}{ Contributions } & \multirow{2}{*}{$\begin{array}{c}\text { cel6A.CB } \\
\text { (kcal/mol) }\end{array}$} & \multicolumn{4}{c}{ cel6A.CBC (kcal/mol) } \\
\cline { 3 - 6 } & & $\mathbf{2 6 . 8 5}{ }^{\circ} \mathbf{C}$ & $\mathbf{6 0 . 8 5}{ }^{\circ} \mathbf{C}$ & $\mathbf{7 4 . 8 5}{ }^{\circ} \mathbf{C}$ & $\mathbf{1 2 6 . 8 5}{ }^{\circ} \mathbf{C}$ \\
\hline$\Delta \mathrm{E}_{\mathrm{ele}}$ & -5.55 & -8.94 & -7.85 & -8.24 & -2.15 \\
$\Delta \mathrm{E}_{\mathrm{vdw}}$ & -14.57 & -23.87 & -22.84 & -20.26 & -13.2 \\
$\Delta \mathrm{E}_{\mathrm{MM}}$ & -20.12 & -32.81 & -30.69 & -28.5 & -15.35 \\
$\Delta \mathrm{G}_{\mathrm{p}}$ & 10.2 & 15.63 & 13.96 & 13.45 & 7.98 \\
$\Delta \mathrm{G}_{\mathrm{np}}$ & -2.09 & -3.45 & -4.82 & -4.21 & -1.62 \\
$\Delta \mathrm{G}_{\mathrm{sol}}$ & 8.11 & 12.18 & 9.14 & 9.24 & 6.36 \\
$\Delta \mathrm{G}_{\mathrm{tol}}$ & -12.01 & -20.63 & -21.55 & -19.26 & -8.99 \\
\hline
\end{tabular}

\section{Conclusions}

All cel6A variants showed a broad range of $\mathrm{pH}$ optima with a $\mathrm{pH}$ range of 5.0 and 8.0 retaining more than $80 \%$ activity, except cel6A.CBC, which retained more than $90 \%$ endoglucanase activity in this range. The optimum $\mathrm{pH}$ for all of the cel6A variants was 6.5. All the cel6A variants showed more than $80 \%$ endoglucanase activity at a temperature range of 55 and $70^{\circ} \mathrm{C}$ with optimum $\mathrm{CMCase}$ activity at $65{ }^{\circ} \mathrm{C}$. cel6A.C without $\mathrm{CBM}$ and cel6A.CBC with a new catalytic domain showed slightly higher thermostability with more than $80 \%$ CMCase activity at $75{ }^{\circ} \mathrm{C}$ after $15 \mathrm{~min}$ of incubation and more than $60 \%$ activity after $30 \mathrm{~min}$ incubation. These results suggested that inclusion of an extra catalytic domain plays an important role in the thermostability of enzyme, while additional CBM reduces its thermostability. Moreover, the MD simulations study showed an excellent rationale with the experimental results and emphasized the thermostable region at higher temperatures. The present study focused on the thermostable cel6A construct, which can potentiate the mass production of bioethanol from plant biomass. On the other side, this study also identified the factors responsible for thermostability of endoglucanase (cel6A) variants from Thermobifida fusca that may endeavour to design enzymes with enhanced thermostability. 
Supplementary Materials: The following are available online at http://www.mdpi.com/2079-7737/9/8/214/s1, Figure S1: Schematic representation of engineering of T. fusca endoglucanase cel6A; Figure S2: Schematic representation of T. fusca endoglucanase cel6A modular architecture; Figure S3: Agarose (0.8\%) gel showing restriction maps generated by digestion of pcel6A.C, pcel6A.BC, pcel6A.BCB, pcel6A.CBC, and pcel6A. Table S1: Primers used for amplification of gene fragments of cel6A. a Restriction sites are bold and underlined.

Author Contributions: I.A. conceived the idea and designed the experiments; R.A. (Rashid Ahmed), M.T., R.A. (Rehana Asghar), F.T. and H.K. performed the experiments and extracted results; M.U.M. and H.M.R. performed the molecular docking analyses; M.U.M. and H.M.R. performed molecular dynamics simulations analysis; I.A., R.A. (Rashid Ahmed), M.U.M. and H.K. wrote the main manuscript text; M.W.A., H.A.A. and M.F. critically reviewed the manuscript. All authors have read and agreed to the published version of the manuscript.

Acknowledgments: Authors extend their appreciation to the Deanship of Scientific Research at King Khalid University for funding this work through research groups program under Grant No. R.G.P-2/49/40.

Conflicts of Interest: The authors declare no conflict of interest.

\section{References}

1. Heinzelman, P.; Snow, C.D.; Wu, I.; Nguyen, C.; Villalobos, A.; Govindarajan, S.; Minshull, J.; Arnold, F.H. A family of thermostable fungal cellulases created by structure-guided recombination. Proc. Natl. Acad. Sci. USA 2009, 106, 5610-5615. [CrossRef] [PubMed]

2. Blanch, H.W.; Simmons, B.A.; Klein-Marcuschamer, D. Biomass deconstruction to sugars. Biotechnol. J. 2011, 6, 1086-1102. [CrossRef] [PubMed]

3. Fischer, C.R.; Klein-Marcuschamer, D.; Stephanopoulos, G. Selection and optimization of microbial hosts for biofuels production. Metab. Eng. 2008, 10, 295-304. [CrossRef] [PubMed]

4. Zhang, Y.-H.P.; Himmel, M.E.; Mielenz, J.R. Outlook for cellulase improvement: Screening and selection strategies. Biotechnol. Adv. 2006, 24, 452-481. [CrossRef]

5. Liu, W.; Zhang, X.-Z.; Zhang, Z.; Zhang, Y.-H.P. Engineering of Clostridium phytofermentans endoglucanase Cel5A for improved thermostability. Appl. Environ. Microbiol. 2010, 76, 4914-4917. [CrossRef]

6. Paës, G.; O'Donohue, M.J. Engineering increased thermostability in the thermostable GH-11 xylanase from Thermobacillus xylanilyticus. J. Biotechnol. 2006, 125, 338-350. [CrossRef]

7. Turner, P.; Mamo, G.; Karlsson, E.N. Potential and utilization of thermophiles and thermostable enzymes in biorefining. Microb. Cell Factories 2007, 6, 9. [CrossRef]

8. Caspi, J.; Irwin, D.; Lamed, R.; Shoham, Y.; Fierobe, H.-P.; Wilson, D.B.; Bayer, E.A.J.B. Thermobifida fusca family-6 cellulases as potential designer cellulosome components. Biocatal. Biotransformation 2006, $24,3-12$.

9. Wilson, D.B. Studies of Thermobifida fusca plant cell wall degrading enzymes. Chem. Rec. 2004, 4, 72-82. [CrossRef]

10. Bolam, D.N.; Ciruela, A.; McQueen-Mason, S.; Simpson, P.; Williamson, M.P.; Rixon, J.E.; Boraston, A.; Hazlewood, G.P.; Gilbert, H.J. Pseudomonas cellulose-binding domains mediate their effects by increasing enzyme substrate proximity. Biochem. J. 1998, 331, 775-781. [CrossRef]

11. Gilad, R.; Rabinovich, L.; Yaron, S.; Bayer, E.A.; Lamed, R.; Gilbert, H.J.; Shoham, Y. CelI, a noncellulosomal family 9 enzyme from Clostridium thermocellum, is a processive endoglucanase that degrades crystalline cellulose. J. Bacteriol. 2003, 185, 391-398. [CrossRef] [PubMed]

12. Beckham, G.T.; Bomble, Y.J.; Bayer, E.A.; Himmel, M.E.; Crowley, M.F. Applications of computational science for understanding enzymatic deconstruction of cellulose. Curr. Opin. Biotechnol. 2011, 22, $231-238$. [CrossRef] [PubMed]

13. Din, N.; Gilkes, N.R.; Tekant, B.; Miller, R.C.; Warren, R.A.J.; Kilburn, D.G. Non-hydrolytic disruption of cellulose fibres by the binding domain of a bacterial cellulase. Nat. Biotechnol. 1991, 9, 1096-1099. [CrossRef]

14. Cheng, G.; Liu, Z.; Murton, J.K.; Jablin, M.; Dubey, M.; Majewski, J.; Halbert, C.; Browning, J.; Ankner, J.; Akgun, B. Neutron reflectometry and QCM-D study of the interaction of cellulases with films of amorphous cellulose. Biomacromolecules 2011, 12, 2216-2224. [CrossRef] [PubMed]

15. Viikari, L.; Alapuranen, M.; Puranen, T.; Vehmaanperä, J.; Siika-Aho, M. Thermostable enzymes in lignocellulose hydrolysis. In Biofuels; Springer: Berlin/Heidelberg, Germany, 2007; pp. 121-145.

16. Kim, T.W.; Chokhawala, H.A.; Nadler, D.; Blanch, H.W.; Clark, D.S. Binding modules alter the activity of chimeric cellulases: Effects of biomass pretreatment and enzyme source. Biotechnol. Bioeng. 2010, 107, 601-611. [CrossRef] 
17. Anbar, M.; Gul, O.; Lamed, R.; Sezerman, U.O.; Bayer, E.A. Improved thermostability of Clostridium thermocellum endoglucanase Cel8A by using consensus-guided mutagenesis. Appl. Environ. Microbiol. 2012, 78, 3458-3464. [CrossRef]

18. Anbar, M.; Lamed, R.; Bayer, E.A. Thermostability enhancement of Clostridium thermocellum cellulosomal endoglucanase Cel8A by a single glycine substitution. ChemCatChem 2010, 2, 997-1003. [CrossRef]

19. Chen, X.; Li, W.; Ji, P.; Zhao, Y.; Hua, C.; Han, C. Engineering the conserved and noncatalytic residues of a thermostable $\beta-1,4$-endoglucanase to improve specific activity and thermostability. Sci. Rep. 2018, 8, 1-10. [CrossRef]

20. Mitrovic, A.; Flicker, K.; Steinkellner, G.; Gruber, K.; Reisinger, C.; Schirrmacher, G.; Camattari, A.; Glieder, A. Thermostability improvement of endoglucanase Cel7B from Hypocrea pseudokoningii. J. Mol. Catal. B Enzym. 2014, 103, 16-23. [CrossRef]

21. Voutilainen, S.P.; Murray, P.G.; Tuohy, M.G.; Koivula, A. Expression of Talaromyces emersonii cellobiohydrolase Cel7A in Saccharomyces cerevisiae and rational mutagenesis to improve its thermostability and activity. Protein Eng. Des. Sel. 2010, 23, 69-79. [CrossRef]

22. Yi, Z.-L.; Pei, X.-Q.; Wu, Z.-L. Introduction of glycine and proline residues onto protein surface increases the thermostability of endoglucanase CelA from Clostridium thermocellum. Bioresour. Technol. 2011, 102, 3636-3638. [CrossRef] [PubMed]

23. Burstein, T.; Shulman, M.; Jindou, S.; Petkun, S.; Frolow, F.; Shoham, Y.; Bayer, E.A.; Lamed, R. Physical association of the catalytic and helper modules of a family-9 glycoside hydrolase is essential for activity. FEBS Lett. 2009, 583, 879-884. [CrossRef]

24. Jervis, E.J.; Haynes, C.A.; Kilburn, D.G. Surface diffusion of cellulases and their isolated binding domains on cellulose. J. Biol. Chem. 1997, 272, 24016-24023. [CrossRef] [PubMed]

25. Kleine, J.; Liebl, W. Comparative characterization of deletion derivatives of the modular xylanase XynA of Thermotoga maritima. Extremophiles 2006, 10, 373-381. [CrossRef] [PubMed]

26. Mizutani, K.; Sakka, M.; Kimura, T.; Sakka, K. Essential role of a family-32 carbohydrate-binding module in substrate recognition by Clostridium thermocellum mannanase CtMan5A. FEBS Lett. 2014, 588, 1726-1730. [CrossRef]

27. Pasari, N.; Adlakha, N.; Gupta, M.; Bashir, Z.; Rajacharya, G.H.; Verma, G.; Munde, M.; Bhatnagar, R.; Yazdani, S.S. Impact of Module-X2 and Carbohydrate Binding Module-3 on the catalytic activity of associated glycoside hydrolases towards plant biomass. Sci. Rep. 2017, 7, 1-15. [CrossRef]

28. Reyes-Ortiz, V.; Heins, R.A.; Cheng, G.; Kim, E.Y.; Vernon, B.C.; Elandt, R.B.; Adams, P.D.; Sale, K.L.; Hadi, M.Z.; Simmons, B.A. Addition of a carbohydrate-binding module enhances cellulase penetration into cellulose substrates. Biotechnol. Biofuels 2013, 6, 93. [CrossRef]

29. Telke, A.A.; Ghatge, S.S.; Kang, S.-H.; Thangapandian, S.; Lee, K.-W.; Shin, H.-D.; Um, Y.; Kim, S.-W. Construction and characterization of chimeric cellulases with enhanced catalytic activity towards insoluble cellulosic substrates. Bioresour. Technol. 2012, 112, 10-17. [CrossRef]

30. Thongekkaew, J.; Ikeda, H.; Masaki, K.; Iefuji, H. Fusion of cellulose binding domain from Trichoderma reesei CBHI to Cryptococcus sp. S-2 cellulase enhances its binding affinity and its cellulolytic activity to insoluble cellulosic substrates. Enzym. Microb. Technol. 2013, 52, 241-246. [CrossRef]

31. Durrani, F.G.; Gul, R.; Mirza, M.U.; Kaderbhai, N.N.; Froeyen, M.; Saleem, M. Mutagenesis of DsbAss is Crucial for the Signal Recognition Particle Mechanism in Escherichia coli: Insights from Molecular Dynamics Simulations. Biomolecules 2019, 9, 133. [CrossRef]

32. Jabbar, B.; Rafique, S.; Salo-Ahen, O.M.H.; Ali, A.; Munir, M.; Idrees, M.; Mirza, M.U.; Vanmeert, M.; Shah, S.Z.; Jabbar, I. Antigenic peptide prediction from E6 and E7 oncoproteins of HPV Types 16 and 18 for therapeutic vaccine design using immunoinformatics and MD simulation analysis. Front. Immunol. 2018, 9, 3000. [CrossRef]

33. Grottesi, A.; Ceruso, M.A.; Colosimo, A.; Di Nola, A. Molecular dynamics study of a hyperthermophilic and a mesophilic rubredoxin. Proteins Struct. Funct. Bioinform. 2002, 46, 287-294. [CrossRef]

34. Gruia, A.D.; Fischer, S.; Smith, J.C. Molecular dynamics simulation reveals a surface salt bridge forming a kinetic trap in unfolding of truncated Staphylococcal nuclease. Proteins Struct. Funct. Bioinform. 2003, 50, 507-515. [CrossRef] [PubMed]

35. Yin, J.; Bowen, D.; Southerland, W.M. Barnase thermal titration via molecular dynamics simulations: Detection of early denaturation sites. J. Mol. Graph. Model. 2006, 24, 233-243. [CrossRef] 
36. Liu, J.; Yu, H.; Shen, Z. Insights into thermal stability of thermophilic nitrile hydratases by molecular dynamics simulation. J. Mol. Graph. Model. 2008, 27, 529-535. [CrossRef]

37. Bae, E.; Phillips, G.N. Identifying and Engineering Ion Pairs in Adenylate Kinases Insights from molecular dynamics simulations of thermophilic and mesophilic homologues. J. Biol. Chem. 2005, 280, 30943-30948. [CrossRef] [PubMed]

38. Parra-Cruz, R.; Jäger, C.M.; Lau, P.L.; Gomes, R.L.; Pordea, A. Rational Design of Thermostable Carbonic Anhydrase Mutants Using Molecular Dynamics Simulations. J. Phys. Chem. B 2018, 122, 8526-8536. [CrossRef]

39. Kundu, S.; Roy, D. Structural study of carboxylesterase from hyperthermophilic bacteria Geobacillus stearothermophilus by molecular dynamics simulation. J. Mol. Graph. Model. 2010, 28, 820-827. [CrossRef] [PubMed]

40. D'Auria, S.; Aurilia, V.; Marabotti, A.; Gonnelli, M.; Strambini, G. Structure and dynamics of cold-adapted enzymes as investigated by phosphorescence spectroscopy and molecular dynamics studies. 2 . The case of an esterase from Pseudoalteromonas haloplanktis. J. Phys. Chem. B 2009, 113, 13171-13178. [CrossRef] [PubMed]

41. D'Auria, S.; Herman, P.; Lakowicz, J.R.; Bertoli, E.; Tanfani, F.; Rossi, M.; Manco, G. The thermophilic esterase from Archaeoglobus fulgidus: Structure and conformational dynamics at high temperature. Proteins Struct. Funct. Bioinform. 2000, 38, 351-360. [CrossRef]

42. Wintrode, P.L.; Zhang, D.; Vaidehi, N.; Arnold, F.H.; Goddard, W.A., III. Protein dynamics in a family of laboratory evolved thermophilic enzymes. J. Mol. Biol. 2003, 327, 745-757. [CrossRef]

43. Cao, R.; Jin, Y.; Xu, D. Recognition of cello-oligosaccharides by CBM17 from Clostridium cellulovorans: Molecular dynamics simulation. J. Phys. Chem. B 2012, 116, 6087-6096. [CrossRef] [PubMed]

44. Li, P.; Zhang, C.; Xu, D. Molecular dynamics investigations of cello-oligosaccharide recognition by Cel9G-CBM3c from Clostridium cellulovorans. Phys. Chem. Chem. Phys. 2018, 20, 5235-5245. [CrossRef] [PubMed]

45. Ali, I.; Ahmad, S.; Asghar, R.; Sajjad, M.; Awan, M.T.; Akhtar, M.W. mRNA secondary structure engineering of Thermobifida fusca endoglucanase (cel6A) for enhanced expression in E. coli. World J. Microbiol. Biotechnol. 2015, 331, 499-506. [CrossRef] [PubMed]

46. Green, M.R.; Sambrook, J.; Sambrook, J. Molecular Cloning: A Laboratory Manual; Cold Spring Harbor Laboratory Press: Cold Spring Harbor, NY, USA, 2012.

47. Ghose, T.K. Measurements of cellulase activities. Pure Appl. Chem. 1987, 59, 257-268. [CrossRef]

48. Bradford, M.M. A rapid and sensitive method for the quantitation of microgram quantities of protein utilizing the principle of protein-dye binding. Anal. Biochem. 1976, 72, 248-254. [CrossRef]

49. Khan, M.I.M.; Sajjad, M.; Ali, I.; Ahmad, S.; Akhtar, M.W. Influence of transposition and insertion of additional binding domain on expression and characteristics of xylanase $\mathrm{C}$ of Clostridium thermocellum. J. Biotechnol. 2010, 150, 1-5. [CrossRef]

50. Sajjad, M.; Khan, M.I.M.; Akbar, N.S.; Ahmad, S.; Ali, I.; Akhtar, M.W. Enhanced expression and activity yields of Clostridium thermocellum xylanases without non-catalytic domains. J. Biotechnol. 2010, 145, 38-42. [CrossRef]

51. Webb, B.; Sali, A. Protein Structure Modeling with MODELLER; Protein Structure Prediction; Methods in Molecular Biology, Humana Press: New York, NY, USA, 2014; pp. 1-15.

52. Söding, J.; Biegert, A.; Lupas, A.N. The HHpred interactive server for protein homology detection and structure prediction. Nucleic Acids Res. 2005, 33, W244-W248. [CrossRef]

53. Chen, V.B.; Arendall, W.B.; Headd, J.J.; Keedy, D.A.; Immormino, R.M.; Kapral, G.J.; Murray, L.W.; Richardson, J.S.; Richardson, D.C. MolProbity: All-atom structure validation for macromolecular crystallography. Acta Crystallogr. Sect. D Biol. Crystallogr. 2010, 66, 12-21. [CrossRef]

54. Case, D.; Ben-Shalom, I.; Brozell, S.; Cerutti, D.; Cheatham, T., III; Cruzeiro, V.; Darden, T.; Duke, R.; Ghoreishi, D.; Gilson, M. AMBER 2018; University of California: San Francisco, CA, USA, 2018.

55. Maier, J.A.; Martinez, C.; Kasavajhala, K.; Wickstrom, L.; Hauser, K.E.; Simmerling, C. ff14SB: Improving the Accuracy of Protein Side Chain and Backbone Parameters from ff99SB. J. Chem. Theory Comput. 2015, 11, 3696-3713. [CrossRef] [PubMed]

56. Price, D.J.; Brooks, C.L., III. A modified TIP3P water potential for simulation with Ewald summation. J. Chem. Phys. 2004, 121, 10096-10103. [CrossRef] [PubMed] 
57. Mirza, M.U.; Vanmeert, M.; Froeyen, M.; Ali, A.; Rafique, S.; Idrees, M. In silico structural elucidation of RNA-dependent RNA polymerase towards the identification of potential Crimean-Congo Hemorrhagic Fever Virus inhibitors. Sci. Rep. 2019, 9, 6809. [CrossRef] [PubMed]

58. Saeed, S.; Bonnefond, A.; Tamanini, F.; Mirza, M.U.; Manzoor, J.; Janjua, Q.M.; Din, S.M.; Gaitan, J.; Milochau, A.; Durand, E. Loss-of-function mutations in ADCY3 cause monogenic severe obesity. Nat. Genet. 2018, 50, 175. [CrossRef] [PubMed]

59. Pettersen, E.F.; Goddard, T.D.; Huang, C.C.; Couch, G.S.; Greenblatt, D.M.; Meng, E.C.; Ferrin, T.E. UCSF Chimera-A visualization system for exploratory research and analysis. J. Comput. Chem. 2004, 25, 1605-1612. [CrossRef]

60. Trott, O.; Olson, A.J. AutoDock Vina: Improving the speed and accuracy of docking with a new scoring function, efficient optimization, and multithreading. J. Comput. Chem. 2010, 31, 455-461. [CrossRef]

61. Larsson, A.M.; Bergfors, T.; Dultz, E.; Irwin, D.C.; Roos, A.; Driguez, H.; Wilson, D.B.; Jones, T.A. Crystal structure of Thermobifida fusca endoglucanase cel6A in complex with substrate and inhibitor: The role of tyrosine Y73 in substrate ring distortion. Biochemistry 2005, 44, 12915-12922. [CrossRef]

62. Iman, K.; Mirza, M.U.; Mazhar, N.; Vanmeert, M.; Irshad, I.; Kamal, M.A. In silico Structure-based Identification of Novel Acetylcholinesterase Inhibitors Against Alzheimer's Disease. CNS Neurol. Disord. Drug Targets Former. Curr. Drug Targets CNS Neurol. Disord. 2018, 17, 54-68. [CrossRef]

63. Hou, T.; Wang, J.; Li, Y.; Wang, W. Assessing the performance of the molecular mechanics/Poisson Boltzmann surface area and molecular mechanics/generalized Born surface area methods. II. The accuracy of ranking poses generated from docking. J. Comput. Chem. 2011, 32, 866-877. [CrossRef]

64. Kollman, P.A.; Massova, I.; Reyes, C.; Kuhn, B.; Huo, S.; Chong, L.; Lee, M.; Lee, T.; Duan, Y.; Wang, W. Calculating structures and free energies of complex molecules: Combining molecular mechanics and continuum models. Acc. Chem. Res. 2000, 33, 889-897. [CrossRef]

65. Sajjad, M.; Khan, M.I.M.; Zafar, R.; Ahmad, S.; Niazi, U.H.K.; Akhtar, M.W. Influence of positioning of carbohydrate binding module on the activity of endoglucanase CelA of Clostridium thermocellum. J. Biotechnol. 2012, 161, 206-212. [CrossRef] [PubMed]

66. Irwin, D.C.; Spezio, M.; Walker, L.P.; Wilson, D.B. Activity studies of eight purified cellulases: Specificity, synergism, and binding domain effects. Biotechnol. Bioeng. 1993, 42, 1002-1013. [CrossRef] [PubMed]

67. Duan, Y.; Kollman, P.A. Pathways to a protein folding intermediate observed in a 1-microsecond simulation in aqueous solution. Science 1998, 282, 740-744. [CrossRef] [PubMed]

68. Duan, Y.; Wang, L.; Kollman, P.A. The early stage of folding of villin headpiece subdomain observed in a 200-nanosecond fully solvated molecular dynamics simulation. Proc. Natl. Acad. Sci. USA 1998, 95, 9897-9902. [CrossRef] [PubMed]

69. Kostylev, M. Studies of Thermobifida Fusca Cellulases Cel9A and Cel48A Using a Novel Kinetic Modeling Approach for the Enzymatic Digestion of Cellulose. Ph.D. Thesis, Cornell University, Ithaca, NY, USA, 2013.

70. Purmonen, M.; Valjakka, J.; Takkinen, K.; Laitinen, T.; Rouvinen, J. Molecular dynamics studies on the thermostability of family 11 xylanases. Protein Eng. Des. Sel. 2007, 20, 551-559. [CrossRef] [PubMed]

71. Liwo, A.; Czaplewski, C.; Ołdziej, S.; Scheraga, H.A. Computational techniques for efficient conformational sampling of proteins. Curr. Opin. Struct. Biol. 2008, 18, 134-139. [CrossRef]

(C) 2020 by the authors. Licensee MDPI, Basel, Switzerland. This article is an open access article distributed under the terms and conditions of the Creative Commons Attribution (CC BY) license (http://creativecommons.org/licenses/by/4.0/). 